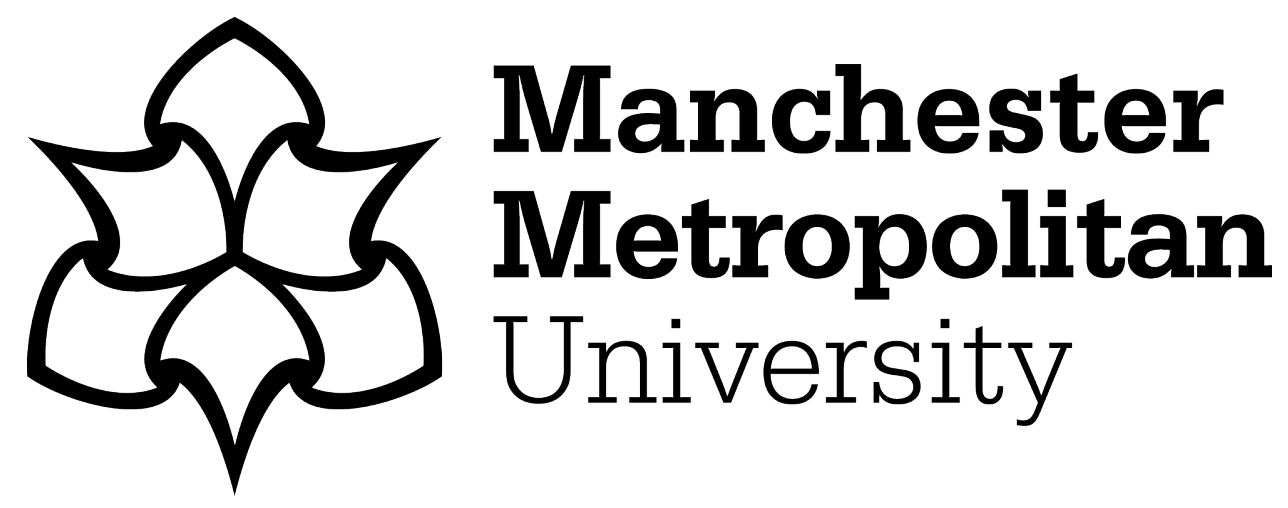

Holloway, J (2017) On the spaces and movement of monsters: the itinerant crossings of Gef the talking mongoose. Cultural Geographies, 24 (1). pp. 21-41. ISSN 1474-4740

Downloaded from: https://e-space.mmu.ac.uk/255/

Version: Accepted Version

Publisher: Sage Publications Ltd.

DOI: https://doi.org/10.1177/1474474016644759

Please cite the published version 


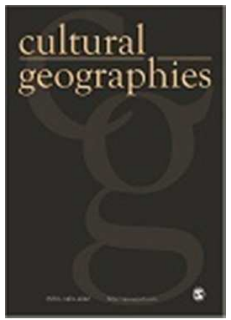

\section{On the spaces and movement of monsters: The itinerant crossings of Gef the talking mongoose}

\begin{tabular}{|r|l|}
\hline Journal: & cultural geographies \\
\hline Manuscript ID & CGJ-14-0123.R2 \\
\hline Kanuscript Type: & Article \\
\hline Keywords: & Monster, Monstrous geographies, Mobility, Supernatural, Isle of Man \\
\hline & $\begin{array}{l}\text { Geographical enquiries of the monster and the monstrous have increased } \\
\text { in recent years. Through the accounting of a particular monster that } \\
\text { emerged in the Isle of Man in the 1930s, I seek to contribute to these } \\
\text { debates. The monster detailed in this paper underscores the argument that } \\
\text { the power of the monster lies in both their proximity to familiar spatial and } \\
\text { cultural codings, and their distance in the unfamiliarity they perform. } \\
\text { However, I argue that the geographical accounts of the monster must } \\
\text { focus their attention not only on their ambiguous status, but how they are } \\
\text { constituted through mobility and movement. It is the constant itinerancy } \\
\text { in-between and in-the-between wherein the monster finds its disruption } \\
\text { and potential. Furthermore, in exploring monstrous modes of mobility, I } \\
\text { argue the monster is best understood as an itinerant crossing that is } \\
\text { incessantly and continually emergent. I finish by reminding those } \\
\text { interested in monstrous geographies that whilst these strange beings may } \\
\text { act as sources of hope and potentiality, geographers must not lose sight of } \\
\text { how the monster still has the capacity to warn and to bite. }\end{array}$ \\
\hline \hline
\end{tabular}

\section{SCHOLARONE ${ }^{m}$ \\ Manuscripts}


On the spaces and movement of monsters: The Itinerant crossings of Gef the talking mongoose

\begin{abstract}
Geographical enquiries of the monster and the monstrous have increased in recent years. Through the accounting of a particular monster that emerged in the Isle of Man in the 1930s, I seek to contribute to these debates. The monster detailed in this paper underscores the argument that the power of the monster lies in both their proximity to familiar spatial and cultural codings, and their distance in the unfamiliarity they perform. However, I argue that the geographical accounts of the monster must focus their attention not only on their ambiguous status, but how they are constituted through mobility and movement. It is the constant itinerancy in-between and in-the-between wherein the monster finds its disruption and potential. Furthermore, in exploring monstrous modes of mobility, I argue the monster is best understood as an itinerant crossing that is incessantly and continually emergent. I finish by reminding those interested in monstrous geographies that whilst these strange beings may act as sources of hope and potentiality, geographers must not lose sight of how the monster still has the capacity to warn and to bite.
\end{abstract}

\title{
Keywords
}

Monster, Monstrous geographies, Mobility, Supernatural, Isle of Man

\section{Introduction}

The familiar exclamation 'Here be Monsters!' has been, and continues to be, a common socio-cultural spatial motif for the unknown and the feared. Such familiar geographical adages reveal the monster to be constituted through liminal spaces at the edge of, and with the power to disrupt, the known world: as Dendle puts it, humanity has "consistently and ubiquitously populated its border spaces with fascinating and sometimes threatening creatures. ${ }^{1}$ Fuelled by a desire to explore this and others spatialities, the monster has figured in a number of geographical enquiries in recent years. ${ }^{2}$ In particular, recent scholarship has revealed that monsters are both liminal and yet very much in our midst through residing in places and practices less peripheral: backyards and puddles, scientific laboratories, environmental management strategies and (of course) art, literature and popular culture, are all home to the monster. ${ }^{3}$ 
How can we make sense of the monster? In overview, monsters are both representative of something and perform a disordering or a disturbance. Historically, the monster was representative of revelation: its very appearance a form of warning or portent. Indeed the etymology of the word 'monster' indicates this:

\author{
"It comes to English from the Latin monstrum. Monstrum, in turn, is derived from a corruption of \\ moneo by monstrare. This links 'advice', 'reminder' or warning with 'showing'. As such, monsters \\ reveal something. To meet a monster is to encounter something surprising in the world; it is to \\ discover the world is not as 'ordinary' or 'familiar' as it might have seemed."
}

On the one hand, the monster could demonstrate a moral transgression or an impending calamity fashioned by God's wrath. On the other, the monster could reveal the fecundity and perfection of nature as God's creation, and hence "served to emphasise by force of contrast the rightness of most forms." ${ }^{5}$ Figuratively, the monster, through its abnormality, acts to patrol and set the precincts of normality: the monster acts as a constitutional outside, contrasting to that which is regular, correct and proper. The policing of the normal is achieved through and against the monster's potential to disrupt and threaten. As anomalous and abnormal, monsters require calculation, categorisation and control: they become "an object for explanation, a matter to be curtailed." ${ }^{6}$ Under the Enlightenment, the study of monstrous abnormalities became a science in itself - teratology - as the previous Ancient and medieval symbolism of monsters as warnings gave way to the need to classify. Yet as Shildrick explains, "Even when the long-standing belief in the supposedly portentous nature of monstrosity lost favour in the face of more naturalistic explanations of Enlightenment science, the requirement of interpretation remained." ${ }^{7}$

Key to the monster's enduring longevity is its ambiguous status or the "category crisis" it produces. ${ }^{8}$ As such, the monster is never wholly Other in that we recognise both our difference from, and connection and similarity to it: the monster's status is both distant and proximate. One only needs to think of Japanese monster Godzilla to exemplify this: abnormal and threatening in its size, appearance and actions, Godzilla's ontology lies in humanity's hubris in nuclear power and weapons, and thus its origins are of our own making. As Shildrick 
Indeed, the performative and affective potential of the monster is something that recent human geography has interrogated. Drawing on Haraway, and the monster's ability to render radically impure modern classificatory systems, and Derrida's notion of the monstrous arrivant, as a vital unknown force that appears unannounced, geographers have been keen to explore how the monster can be a figure of renewal and even hope. ${ }^{10}$ The monstrous arrivant then is unforeseen and unforeseeable, its appearance is often sudden and always without prediction. Indeed, to predict the monster is to already know it, to have calculated and comprehended it in advance of its arrival, and in so doing have tamed and undermined its potential. The very status of the monster is transformed here into something promissory, as the improbable allows us to sense the force of things not yet realised: as Dixon and Ruddick argue "We have come to rely on the monstrous to undertake a different kind of labor, not of maintenance, but upheaval, a kind of renewal". ${ }^{11}$ Here the monster speaks to the future as future; to save its potential the monster is left deliberately unknowable, as Derrida has it, "A future that would not be monstrous would not be a future; it would already be a predictable, calculable and programmable tomorrow." $^{12}$

The monster, therefore, has moved from something that warns of transgression, to the object of intellectual explanation, to a figure that holds out promissory unknown futures laden with potential. Through this movement, the monster has disturbed, transformed and yet continues to delight and enchant. Indeed, this paper argues and highlights that it is precisely movement and mobility that are central to understanding the geographies of monsters and monstrous geographies. As such, as well as contributing to debates that explore 


\section{Monstrous disruptions through mobility I: classification, affect and propriety.}

The place for this monstrous tale is the Isle of Man, a thirty two mile long island in the Irish Sea at the geographical centre of the British Isles and a crown dependency of the United Kingdom. The island has and continues to contain its (perhaps more than) fair share of folkloric monsters and anomalous creatures. ${ }^{13}$ For example, residing in the shadows of Greeba Mountain to the West of the capital Douglas lives the famous Buggane, an enormous subterranean ogre-like creature covered with black hair and sporting viscous claws and tusks renowned for ripping the roof off the local church, St. Trinians (which has yet to be repaired). In a less violent spirit, the Phynodderree or Fynoderee is a brownie or sprite that, in payment for food and drink, performs agricultural tasks for local farmers; and the Arkan Sonney, a long haired pig or hedgehog considered lucky if caught. This local bestiary shares the island with ghosts such as a spectral black dog, the Moddey Dhoo, said to haunt Peel Castle on the West coast; and fairies, locally known as 'themselves', which inhabit Fairy Hill at Cronk Howe Mooar and Fairy Bridge on the $\mathrm{A} 5$ road to Castletown in the South. ${ }^{14}$ However, whilst the 
monster that takes centre stage in what follows shares some characteristics with this supernatural panoply, it arguably succeeded in, through its mobile infamy and the extent of its travels, transcending and having greater geographical reach than most of the marvels told of in local folklore.

It could be assumed, that the early part of the twentieth century and the specific period of this monster's emergence - the 1930s - would be a time when such folkloric, superstitious and mythic phenomenon would have been all but eradicated by the various forces of disenchantment. ${ }^{15}$ Yet, on the Isle of Man, this period was one where the Moddey Dhoo was sighted (in 1927 near Ramsey), one where ghostly spirits manifested signalling death (so called 'death apparitions'), fear of fairy abductions still held sway, and in Glen Maye, near where this monstrous case study takes place, a water spirit was said to haunt. ${ }^{16}$ Indeed, on a wider scale, the popularity of spiritualism was still strong over in the UK, after seeing a resurgence after the First World War, well known mediums such as Helen Duncan were in strong demand (leading, in 1944, to her being the only person charged and convicted under the 1735 Witchcraft Act), and the hauntings of Borley Rectory were making headlines in The Daily Mirror. Furthermore, the Society for Psychical Research continued to apply scientific rigour to their investigation of extraordinary human powers, occult and esoteric ideas groups still flourished, and the ideas in which they dealt remained an influence on artistic Modernism (such as Schoenberg in music, Kandinsky in art and Yeats in literature). ${ }^{17}$ In popular culture, Hazelgrove remarks “Along Blackpool's seafront in 1937, faith healers, astrologers and herbalists jostled with Buddhist healers and snake charmers", and Mass-Observation records the meetings of groups like the Mazdaznans in Bury, outside Manchester, where New Thought, esotericism and vegetarianism freely mixed. ${ }^{18}$ It would seem, therefore, that the cultural climate was still ripe for the appearance of something marvellous, strange and seemingly unknown.

On February $12^{\text {th }} 1932$ a Miss Florence Milburn, resident of Peel on the Isle of Man, wrote to the famous ghosthunter and psychic investigator Harry Price. Price described how: 


\begin{abstract}
“My correspondent informed me that a farmer friend of hers, a Mr. James T. Irving, had discovered in his house an animal which, after a little coaxing, had developed the power of speech, and was practically human, except in form." ${ }^{19}$
\end{abstract}

Price wrote to Mr. Irving, who confirmed the story as set out by Miss Milburn: on the $13^{\text {th }}$ of September 1931. Mr. Irving, a former travelling salesman, had heard tapping noises coming from the attic of the farmstead he shared with his wife Margaret and 13 year old daughter Voirrey [INSERT FIGURE 1 HERE]. Over the next few nights the tapping was accompanied by what Mr. Irving described as "animal noises" consisting of "barking, growling, spitting and persistent blowing." ${ }^{20}$ Undertaking a search for the source of the noises, the farmer found nothing. The noises seemed to originate from behind the wooden panelling that lined the walls of the farmhouse in Doarlish Cashen near Dalby on the west of the island. The farmer attempted to get rid of "his unwanted guest [using] gun, trap, and poison in turn, but the knowing creature eluded them all." ${ }^{21}$ Irving then revealed how:

“...something more happened that made us speechless with amazement and apprehension. This strange animal - whatever it was - was making gurgling sounds like a baby trying to talk for the first time! It sounded like this - 'DOMADOMADOMA-BLUMBLUMBLUM.'”22

The intangibility of the thing behind the wooden panelling was echoed by meaningless sounds it uttered.

A few days later Irving decided that the creature might be able to imitate animal sounds: the thing obliged. He wrote, "In a few days, we had only to name the particular animal or bird, and instantly, always without error, it gave the correct call." ${ }^{23}$ Within a few more days the creature was able to repeat nursery rhymes read out by Voirrey. Questions flew between the family and the thing now able of human speech in a voice "extremely high pitched, above the human range, in a clear, sweet tone." ${ }^{24}$ Immediately, we see the thing's first monstrous disruption: the creature transgressed and supplemented the rupture that holds language as the "uber signifier" of the ontological distinction of human and non-human. ${ }^{25}$ The monster moved between both the material 
bounds of wall and wood panelling, and ontologically between human and non-human. Key to the monster's constitution therefore, is the movement in such in-between spaces, both material and symbolic.

The thing demanded knowledge and its questions answered on all manner of subjects. The Irvings named it, or it names itself, Gef - it is unclear who named who. The Irvings demanded to know more; in response Gef stated:

“I am an earthbound spirit.","26

“I am not a spirit. I am a little extra, extra clever mongoose." ${ }^{27}$

"I am a ghost in the form of a weasel and I'll haunt you"28

"I am a freak. I have hands and I have feet, and if you saw me you'd faint, you'd be petrified, mummified, turned into stone or a pillar of salt." ${ }^{29}$

"I am the Holy Ghost"

"I am the fifth dimension, I am the eighth wonder of the world, I can split the atom"

James Irving stated, "Whatever Gef is, animal only, or spirit in this form, there has never, I am sure, been anything like it on this earth before. ${ }^{\prime 32}$ Thus Gef became monstrous in his ambiguous, imponderable and supplementary ontology - he was an animal capable of speech and a desire for human learning and knowledge. This monstrous state was further accentuated through his self-claimed grafting of supernatural origins and abilities - he was a spirit, a weasel, a ghost with human hands and feet, and a mongoose that could talk and imitate animals and birds. Through his ambiguous and seemingly impossible conflation of human and nonhuman, natural and supernatural categories, Gef the talking mongoose disrupted the normalised order of nature and human/non-human dualities. ${ }^{33}$ Accordingly, this disruption required action to try to comprehend: Price dutifully sent a friend, a Captain Dennis, to the Isle of Man to investigate. ${ }^{34}$

The Captain arrived on February $26^{\text {th }} 1932$. He spent a few days on the island and came away with scant evidence, apart from hearing a shrill voice shouting 'Go away, who is that man?', being ordered by Gef to shout 
out 'I do believe in you Gef', and witnessing a large needle being thrown at a teapot. He returned to London, yet Gef continued to interrupt everyday life at Doarlish Cashen with his constant enquiries, knocking, thumping and tricks. On one occasion, Irving remarked "he commenced talking at 11.0 p.m. and he continued until $\underline{3.0}$ $\underline{\text { a.m. }}$, without a stop. Sleep was impossible, and at 3, I said I wished he would go. He said "I am not going to do what you wish. I can stay till 5, if I like." ${ }^{35}$ As time wore on the Irvings grew accustomed to Gef, but admitted "[we] can influence, but cannot control him entirely." ${ }^{36}$ Irving stated how the family only caught glimpses of Gef, yet they were able to describe him as having a "yellowish tinge, like a ferret. The tail is long and bushy and tinged with brown. In size, it is about the length of a three-parts grown rat in the body, without the tail." ${ }^{37}$

Between 1932 and 1936 Gef's activities and abilities grew ever more varied: he took an active interest in transport of different kinds; learnt to read by hiding in class at a local school; became fascinated by current affairs by reading newspapers over James Irving's shoulder; via the farmer's instruction and what he picked up around the Island, he became conversant not only in Manx, but German, French, Italian, Spanish, Arabic, Russian, Yiddish and Welsh, as well as the basics of sign language; he developed a 'considerable' knowledge of medical terms; and claimed, "If you knew what I know, you'd know a hell of a lot" ${ }^{38}$ Other activities included a fondness for singing, listening to the gramophone and bouncing a ball in time to the music in his 'sanctum' - a boxed-off partitioned area of Voirrey's bedroom. ${ }^{39}$ In return for his favourite foods of "chocolates, bananas, biscuits, lean bacon, sausages, potato pie, etc.", Gef provided the family with rabbits. ${ }^{40}$

His attitude to the Irvings varied over the years from warmth and affection to sarcastic observations and outright hostility; prone to angry outbursts and actions, he told the Irvings "You don't know what mischief I could do if I was roused. I could kill you, too, if I wished, but I won't." ${ }^{41}$ In turn, echoing his monstrous misbalancing of both human and nature, witnesses' reactions moved between marvel and incredulity, and senses of delight and wonder: as Irving summated "Our experiences are so wonderful and incredible, that I doubt if the like has ever occurred before on this earth." ${ }^{42}$ Gef's monstrosity then, "cannot be confined to the place of the other; [he] is not simply alien, but arouses the contradictory responses of denial and recognition, disgust and empathy, exclusion and identification". ${ }^{43}$ It is this simultaneous proximity and distance to the 
human witnesses, and the similar ambiguous reactions he engenders, that provides for Gef's monstrosity: “It is, then, in [monster's] failure to wholly and only occupy the place of the other that such monsters betray the fragility of the distinctions by which the human subject is fixed and maintained as fully present to itself and autonomous ${ }^{\prime 44}$ More precisely, it is in his spatial constitution as mobile, through continually moving betwixt and between ontological classifications and consistent affective states, that Gef finds his monstrous geographical being. The monster here is inherently spatially mobile through his movement in and between multiple formations and, furthermore, the impact this movement has.

This performative spatial disclosure through movement continued to exert a pressure to investigate or to stabilise. Consequently, Price and his friend, Richard Stanton Lambert, editor of The Listener magazine and governor of The British Film Institute, visited the Isle of Man in an attempt to make sense of Gef. They arrived in Douglas on July 30th 1935 and made their way up to the farm at Doarlish Cashen. Yet prior to their arrival Gef had gone missing, exclaiming before he left "Captain Dennis can come, but not Price. He's got his doubting cap $\mathrm{on}^{\prime \prime 5}$, and describing Price as the "man who puts the kybosh on the spirits." ${ }^{\prime 46}$ On meeting Margaret and Voirrey the investigators waited for Gef to make himself known. Price then recalled how:

\begin{abstract}
"I addressed a little speech to the four walls of the room, hoping Gef would hear me. I pointed out that we had come a long, long way on his account and that we were entitled to some manifestation: a few words, a little laugh, a scream, a squeak, or just a simple scratch behind the panelling. I even invited him to throw something at me. But all to no purpose: Gef was definitely not in a talking mood., ${ }^{\prime 47}$
\end{abstract}

Gef's unpredictability and improbability eluded Price and Lambert's attempt to impose order and stability. They returned to their hotel and the disturbing power of the monstrous to be registered in ambiguous reactions of wonder and confusion was revealed again:

\footnotetext{
“Neither Mr. Lambert nor I slept very well. The mongoose problem obsessed our minds and made sleep difficult. Was the whole affair a fraud from A to Z? Was it a plot (lasting four years) to fool the
} 
countryside? If so, what was the motive? Were the Irvings engaged in a clever and picturesque conspiracy? Was there any sort of animal at all? Was there any real evidence whatsoever that Gef had been heard? These and similar questions raced through my brain." ${ }^{\prime 4}$

Gef baffled, he raised questions that remained unanswered and affected a misbalancing of self-composure. In so doing he performed a breach of the seemingly coherent and rational subject. James Irving, for example, was troubled by the pervading energy of monstrosity that organised his thoughts and actions: in his correspondence, he constantly sought assurance that his fantastic accounts were not policed as the outpourings of a deviant or becoming-abnormal mind, commenting "You have seen me, my wife and daughter and you will know that none of us have delusions, illusions or hallucinations on any subject." ${ }^{49}$ In 1934, he sought to stress his role as mere witness: "There are hundreds of similar incidents to this, and others besides and if we have had these most extraordinary, amazing and incredible experiences, they came to us, we certainly did not go looking for them.. ${ }^{50}$ In Irving's letters to Dennis and Price the troubling and uncertain itinerant origins of Gef are a constant thematic: "the brain, intellect and knowledge is that of a human being and a superhuman at that and if he is not supernatural, he is certainly uncanny.".51

In 1936 Price and Lambert co-authored The Haunting of Cashen's Gap: A Modern 'Miracle' Investigated.

[INSERT FIGURE 2 HERE] The book maintained Gef's monstrous ambivalence and disruption. In the introduction, Price and Lambert outlined their position as in-between definitive accounts:

\footnotetext{
"To believers it will represent a proof of miracle; to sceptics a lesson in the laws of evidence. Some will cast it nonsense from first to last; others will admit it to be at least as good as most ghost stories.

Throughout we have sought to avoid mere credulity on the one hand and prejudiced scepticism on the other." $^{52}$
}

The monster's power was not limited to improbable movement in-between emotional states and classificatory criteria. Upon the reception of Price and Lambert's book, Gef's monstrous mobility was underlined: Gef moved 
from the culturally coded periphery to the centre, and in-so-doing his impact gained greater geographical reach. This movement began on February $7^{\text {th }} 1936$, when Sir Cecil Levita and Mr. William Murray had lunch at the Carlton Club in London. Sir Cecil was a former Chairman of the London County Council and Home Office Advisor on film censorship and through his wife's role with the British Film Institute he was an acquaintance of Richard Lambert. Murray, who had previously been Director of Information and Publications at the BBC and therefore Lambert's superior at The Listener, later reported how he found Sir Cecil at the meeting:

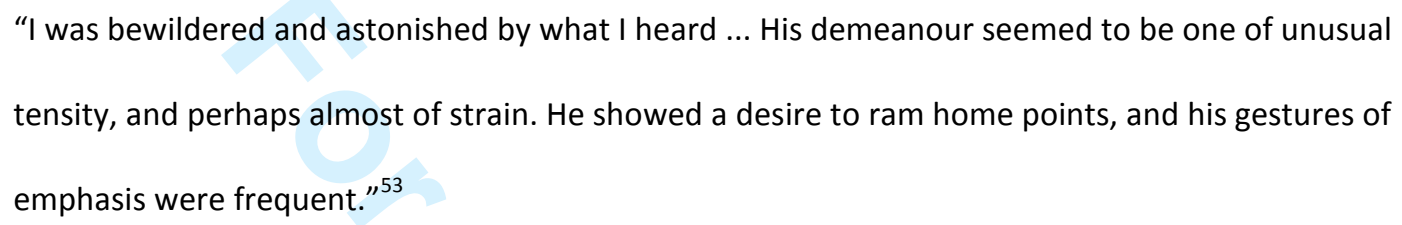

The subject of their discussion, which so affected Sir Cecil's deportment, was Lambert's investigation into the talking mongoose. Sir Cecil maintained that because of his visit to the Isle of Man and speculations about Gef, Lambert was unfit to remain a governor of the BFI. During the meeting Sir Cecil "touched his forehead when he was speaking of Mr. Lambert to indicate lack of mental balance." ${ }^{54}$

Thus Gef's power to disturb, to upset normalised and normative modes of action and demeanour, was realised in Sir Cecil's agitation at the luncheon meeting: here the talking mongoose becomes an absent but mobile presence orchestrating modes of intense affect that leave Murray, as witness to this agitation, in a state of concern and doubt. Sir Cecil's impropriety, afforded through Gef's troubling ontology and movement, is paralleled through the accusation that the mongoose had over-turned Lambert's faculties and mental stability: both are seemingly possessed or have come under the influence of Gef's disquieting practices and uncertain status. Moreover, Gef's affective force has become mobile: his monstrosity is able to travel and circulate beyond the Isle of Man to the metropole and the heart of national and public institutions. In other words, the spatial constitution of the monster as mobile is further underlined, as Gef both travels and affects at a distance. ${ }^{55}$ Consequently, the mobile monster must be made stable or denied free travel through settling Gef as 
a fraud and curtailing his affect; something Levita thought possible through hoping to dismiss Lambert as a governor of the BFI and from The Listener.

Murray informed Lambert of the lunch meeting and Lambert wrote to Sir Cecil demanding an apology, but received only a note from Sir Cecil's solicitors informing him that they would only offer a formal reply after it had been discussed by "high officials at the BBC." ${ }^{56} \mathrm{~A}$ concerned Lambert began to believe that there was a conspiracy to depose him at The Listener and he threatened legal action if the lunchtime statements were not withdrawn. After a series of meetings with senior BBC officials, including its Chairman Mr. R.C. Norman, failed to assuage Lambert's fears that his position was under threat, on the $6^{\text {th }}$ of March he issued a libel writ to Sir Cecil Levita.

The case opened on the $4^{\text {th }}$ of November 1936 at the King's Bench Division of the High Court before Justice Sir Rigby Swift and a special jury. The prosecution alleged that Sir Cecil had slandered Lambert through stating that:
"Some months ago [Lambert] fell under the influence of Harry Price and has been heard to express belief in the occult, notably the talking mongoose. Also he has moved his house three times because of pursuit by the evil eye. Things like this have so upset Mr. Lambert's judgment that he is not competent as a governor of the Film Institute. ${ }^{157}$

Furthermore, Sir Patrick Hastings KC, acting on behalf of the plaintiff, argued that Sir Cecil had claimed Lambert was "a person of unstable mind who suffered from illusions and whose judgment and critical faculty were not to be relied on", "that he was mad", and that he "was utterly unfit for the position that he held." ${ }^{58}$ Thus, the transgressive capacity of the monster to upend coherency and the anchors of rationality and judgment needed to hold public office, were realised through Sir Cecil's alleged slander. Moreover, the possession of Lambert's reason had been affected by the contagious, almost mesmeric, powers of those that dabbled in the occult, namely Price; not only did Gef have the power to seize the intellect and lead it in troublesome directions, but 
“'MR. JUSTICE SWIFT. - Does a mongoose in the Isle of Man have a tail? (Laughter.)

MR. BERESFORD. - On the cover of the book it is given a much bushier tail than the ordinary mongoose." ${ }^{61}$

"'SIR PATRICK: Did you ever believe in the mongoose? - No, I did not. Did you ever tell anybody you did? - No. Do you now? - No.

MR. JUSTICE SWIFT - You wait until this case is over! (Loud laughter)'”62

Indeed when Gef was described, "Sir Patrick's recital of these particulars caused considerable laughter in court". ${ }^{63}$ Gef, who was "quite proud" of his mobile impacts, performed his unsettling actions at a distance as the sobriety of the legal space was made temporally playful. ${ }^{64}$ 
The case lasted for three days with Sir Cecil denying that he thought Lambert mad, but insisting that he thought him "ill-balanced." ${ }^{65}$ The jury found in favour of Lambert by agreeing that Sir Cecil did speak the words he was accused of, that the words were untrue, and that they were spoken maliciously. Lambert was awarded $£ 7,500$. The case made the headlines and became known, inevitably, as the 'The Talking Mongoose' case. Sir John Reith declared Lambert's award as "amazing and monstrous." ${ }^{\text {"66 }}$

Although the BBC was not directly being sued by Lambert, many at the time saw the case as one man versus the corporation. ${ }^{67}$ Indeed, Justice Swift in his summing up implicitly criticised the BBC, for at least being allowed to be approached by Sir Cecil:

\footnotetext{
"It was a dreadful thing, when a man in a public position was affronted and outraged and brought an action demanding redress for the wrong which had been done him, that his employers should be approached behind his back and asked to bring pressure to bear on him to settle the matter."${ }^{68}$
}

Furthermore, Sir Stafford Cripps MP criticised the BBC in the House of Commons over its handling of the Lambert case, and as a result Prime Minister Stanley Baldwin directed a Special Board of Inquiry to be set up. Headed by Sir Josiah Stamp, the inquiry into 'certain statements made in the course of the recent case Lambert v. Levita affecting the British Broadcasting Corporation' delivered its report, commonly known as The Stamp Report, on the $15^{\text {th }}$ of December 1936. Although the report makes no direct reference to Gef, it is possible to read it with Gef as a mobile and coordinating force. In thoroughly detailing the machinations that lead to the Lambert vs. Levita case, Gef's monstrous mobility exerts a form of pressure on the inquiry:

\footnotetext{
"He [Norman] also spoke of the documents shown to him by Sir Cecil, which had made him apprehensive of the possible repercussions on the B.B.C. if the case came to Court; and indeed Mr. Lambert himself frankly admitted to us that the documents would make an unfavourable impression
} 


\section{Monstrous disruptions through mobility II: proximity, stasis and materiality.}

So far in this paper I have chosen to explore how the monster's ontology is one that disrupts through a spatiality of movement and mobility. Thus monstrous geographies are produced through an unsettling itinerancy in between and in-the-between of categorical formations (of human/non-human) and affective states (wonder/disbelief, rationality/irrationality), and through a mobility across space (such as acting at a distance upon national institutions). As we have seen, Gef is both close to and different from a variety of normalised categories, and is spatially constituted as both proximate and distant, whilst consistently moving between such states. In this section, I wish to explore how this movement of direction towards and away from both the familiar and the strange is further sustained through the mapping of the farm at Doarlish Cashen and representations of the Irvings. In so doing, Gef further underscores the affective and performative power of monsters, and allows us to explore their spatialities in more depth. 
Many others attempted to investigate and record Gef. For example, the Hungarian psychic investigator and psychoanalyst, Dr. Nandor Fodor, spent a week "trailing this fabulous animal in $1936 .{ }^{\text {71 }}$ He interviewed the Irvings and the local population in attempt to make sense of the phenomenon. Yet by this time Gef was resentful of visitors. Consequently, despite gathering more data on Gef, Fodor failed to 'bottle' Gef and could only (initially at least) conclude, "I cannot prove he is an animal. I have not seen him. He did not talk to me. He claimed to be an animal. I cannot disprove that claim" ${ }^{72}$ Moreover and key here, Fodor's account is caught between, and constantly moves across, certain value judgements concerning the spatialities of the normal/abnormal and the proximate/remote at Doarlish Cashen: "The air, 750 feet above sea level, is remarkably pure and invigorating; its water is excellent. The members of the Irving family are very healthy. They are normal apparently in every respect" ${ }^{73}$ As such, Fodor's description of the Irving's normality was framed by an unstated set of assumptions that the monstrous events occurring in Doarlish Cashen could be mapped and environmentally determined by the peripheral and extraordinary spaces in which they resided he expected the abnormal events to be constituted by an abnormal family in an abnormal space, yet they could not be fixed as such.

Similarly, Price and Lambert moved between accounts of, on the one hand, the marginal landscape (which would seemingly account for and even necessitate the abnormal events) and, on the other, the incongruous yet suburban normality they discovered: "Their house is remote from the world, on a desolate windswept down yet they dress, speak and behave as though they belonged to ordinary suburbia"74 ; and "Both the neat parlour and the larger living room are more comfortable and tastefully furnished than one might expect to find in such an out-of-the-way place." ${ }^{75}$ Thus commentators were caught between recognising the family as comfortably proximate in their normality, and the assumption that the marginal space would be the determining cause of the monstrous. The monstrous Gef is thus geographically constituted through and performs a series of spatial disruptions where an incongruous movement in-between the proximate and distant, the familiar and strange, the expected and unexpected is central. 
James Irving, as witness to the monster, became increasingly shunned and labelled the outcast by the local community over the period: "There is an uneasiness in the air in Glen Maye and Peel, when Mr. Irving heaves in sight. He always knows something which people would prefer him not to know." ${ }^{\prime 76}$ Echoing the attempts at control by other investigators, naming Irving as the outsider from the 'marginal' space of Doarlish Cashen enacted a spatial discursive strategy that sought to apprehended and stabilise the monster emerging therein. Located, fixed and denied movement in this way, Irving and the monster posed little threat to reason, sense and normality. This geographical arrest is further sought in Fodor's epilogue to the Gef story written fourteen years after his investigations. Here, Fodor argues that Gef was "somehow" the unconscious outpourings of James Irving's "frustrated self." ${ }^{77}$ This frustration is mapped and spatially constituted through the peripheral landscape of the farmstead:

\begin{abstract}
"As a commercial traveller, originally, his horizons were too wide, both physically and mentally, to reconcile himself to the cabined and confined life of a sheep and goat farmer in a God-forsaken spot where he was constantly struggling against physical starvation." ${ }^{78}$
\end{abstract}

For Fodor, the imprisonment of Doarlish Cashen becomes the cause and explanation of the monstrosity enacted there, as Irving's psyche seeks subconsciously the freedom from incarceration that Gef both offers (through fame) and denies (through infamy). Indeed, this geographical reading sought to explain away the monster as the product of an immobile and spatially limited subconscious. This spatial lack is echoed and extended in turn by Price and Lambert:

\footnotetext{
"If we were to construct a theory to account for all of this, we should begin by reminding ourselves of the unusual economic and social environment in which the family at Doarlish Cashen has lived for the past twenty years. Isolation, together with lack of many of the occupations which ordinarily fill up a farmer's time, may produce a disposition towards introspection and a tendency to confuse fact with fancy." ${ }^{79}$
} 
Immobilised in a marginal space, the course of rational judgement is disrupted. In these explanations, Gef is caused by a lack of movement and the outside( $r$ ) space in which he emerged: the assumption here being the abundantly mobile Gef provided the escape that the family desire, and hence the monster is constituted in relation to this immobilisation and imprisonment.

In these readings, the monster, as mobile across and beyond spaces of immobility, becomes a flight of fancy. Indeed Gef, in recounting his history, claims to have been an extra-mobile beast from the start: he told of how he was born near Delhi, India, on 7 June 1852 and travelled to the Isle of Man via Egypt, where he had seen the Sphinx "Rising out of the sand." ${ }^{80}$ Further travels ensued during his stay in the Isle of Man, as he traversed the island gathering gossip and news for the Irvings - much of which is corroborated by James Irving. Gef often claimed his means of transport involved hiding on the underside of buses, leading local mechanic, Mr. John Cowley, to exclaim: “This animal, or whatever it is, knows a darn sight too much." ${ }^{81}$ Irving reported, "Now whatever Gef is, he is a most restless, wandering roamer, travelling all over the place at times, but always returning sooner or later to what he calls home (Doarlish Cashen)." ${ }^{82}$

Furthermore, the very manner of Gef's movement was often abnormal:

\begin{abstract}
“Out of doors, when walking side by side with Voirrey, his voice appears to be in the air, and not a foot away from the back of my head, and that he is there in body also, I am in no error as he strikes me continuously will small stones. Indoors the voice moves about the house as quick as wireless, so rapidly in fact, that obstructions to his bodily movements do not seem to exist, and there are neither walls, partitions or doors to impede his movements." ${ }^{13}$
\end{abstract}

Equated here with modern media, Gef seemed to embody a curious mode of mobility: he travelled at unnatural speeds and in inconsistent directions. ${ }^{84}$ He seemed to be unbounded by commonplace or normalised modes of movement, and had a "talent for boundless flight, for lightness, frictionless, free mobility." ${ }^{85}$ Thus, Gef's durable, if strange, form morphed into something immaterial, airy and hyper-mobile as he moved. Gef 
embodied a monstrous lack of fit through an unknowable mobility: he escaped and he exceeded in his liberated movement the spatial strategies that sought to immobilise both him and his witnesses. Put differently, the story of Gef as monster is not only performed through a defiance of spatial classification, it is a story enacted through the defiance of habitualised movement and mobility. In both his strange movement and as a flight of fancy, the monster emerges through a spatiality of curious mobility.

Gef seems to have been, at times, bound to and emergent through the farmhouse (through his knocks on partitioned walls and 'sanctum'), whilst simultaneously transcending, making mutable its construction and taking flight elsewhere. For example, Price and Lambert mapped the farmhouse and surrounding areas, examining the 'runs' between the panelling and walls through which Gef moved and 'peep holes' through which Gef watched visitors and the Irvings, but all to no avail. This movement in space and his improbable ontology meant that investigations often coalesced around the very issue of Gef's materiality; his substantive nature and the nature of his substance. James Irving commented:

\begin{abstract}
"I think I mentioned in a previous letter, that his front feet appeared to be hands. Now on several occasions, I have found the imprint of these hands, or fingers (3) in the fine dust upstairs in a place I know he frequents, they were nearly as long as my own fingers which are short, but not so broad, and they had a fair spread. The animal said, when questioned as to his hands, that they are as large as a big doll's hands, and that he had 3 fingers and a thumb. There was no thumb mark visible in the dust. He can pick up even a small pin, as he has thrown them at me when vexed”86
\end{abstract}

Gef allowed Margaret and James to stroke him through a crack in the wall, but "on one occasion, he stroked my wife's fingers so rapidly with his, that his finger nails tore the skin so much that the finger actually bled, much to Gef's distress." ${ }^{87}$ Irving stated how "My wife has often placed a finger in his mouth, and felt his upper and lower teeth and Gef has taken hold of my wife's fingers in his hand. Emphatically, it is a hand, 3 long fingers and a thumb. She says the grip is that of a vice.." ${ }^{88}$ 
In March 1935, Gef deposited some of his hair on the living room mantelpiece. It was sent to Price, who forwarded it to Mr. F. Martin Duncan, a Fellow of the Zoological Society. Duncan wrote to Price stating:

"I have carefully examined them microscopically and compared them with hairs of known origin in my collection. As a result I can very definitely state that the specimen hairs never grew upon a mongoose, nor are they those of a rat, rabbit, hare, squirrel, or other rodent, or from a sheep, goat, or cow. I am inclined to think that these hairs have probably been taken from a longish haired dog or dogs..." ${ }^{89}$

On receipt of a clipping of hair from Mona the family sheepdog, Duncan's suspicions were confirmed - the hair samples had the same source. Gef provided more evidence of his materiality through pressing his paws into plasticine saying, "I put my foot in it and gave it a twist, but the stuff was hard as hell." 90 The casts were sent to Reginald Pocock of the Natural History Museum, who concluded that they represented no mammal known to him, particularly in the disparity in size of the prints. Gef's very materiality moved in-between familiarity - the hoax of the sheepdog hairs - and the indecipherable - his unknown substance referenced in the paw print casts. As such, in both his airy hyper-mobility and his strange matter, he disclosed and moved in-between the apparently stable orderings of matter and predicable movements.

\section{The consequences and potential of monsters}

"It is said that there is nothing new in heaven or on earth, this maybe, is the preliminary to the discovery of a most weird and uncanny species of nature such as has never previously been heard or seen." ${ }^{91}$

“Here, then, we have a preposterous case - a palpable absurdity... What are we to make of it? What indeed!"92

In this final section I wish to explore what to make of Gef and hence to investigate what he performs and his significance. Put simply, why is Gef important? What does Gef do for human geographical enquiry of the 
In some accounts, Gef emerges as the classical chimera of different parts, grafting together mongoose and human abilities; a hybrid of possible parts and knowable materialities, producing anxiety about what nature and matter is capable of and reflecting back on what human beings consist of; "as unknown to nature as the centaur or the mermaid. ${ }^{\prime 93}$ Yet as we have seen, Gef exceeds and moves across and in-between the amalgam of stable categories of the chimera: Gef is the hybrid of known, possible and impossible/improbable parts. He is partly natural (performing his 'functions' through cracks in the wall), but he is part spirit (he claimed to be both visible and invisible); he is part animal (catching hundreds of rabbits and routing mice from the farmhouse) and part poltergeist through his ability to move and throw objects unseen; he is part ghost, part talking animal. Gef fluctuates between less-than-material and more-than-natural elements of his constitution. Therefore, Gef the monster allows us register the mutability and mobility of matter, how it can morph and move between the knowable and unknowable, and how it might never be settled. In this paper, the site of this movement is precisely the and between mongoose and human, poltergeist and rabbit killer. By giving emphasis to the movement in the between, here signalled by a focus on the 'and', the analytical scope of studies of monstrous geographies can be extended. We must look therefore to the movement in-the-between to explore the geographies of monsters and their spatiality.

Furthermore, the monster is not just constituted through movement across natural materialities and supernatural phenomenon: his ontology is a movement across and in-between accounts (Irving's, Price and Lambert's, Fodor's, local newspapers, etc.); his own narration; his abilities (throwing, catching, talking, learning); the spaces in which he occurs (familiar and strange, close and distant); his defiance of spatial 
classification and his airy hyper-mobility; the traces (in dust in the farmstead, in killed rabbits, in plasticine) he leaves; the disturbances he enacts; the imaginations that potentially conjured him; and the affective trajectories (of wonder, suspicion, annoyance, and more) he mobilises. Thus Gef reveals himself as hybrid of word, agency, flesh, matter, affect, space-time, velocities, modes of mobility and imagination - all of which it seems necessary to chart in order to explore monstrous geographies. However, the notion of hybrid lacks the sense of mobility that I have argued is so central to this monster's constitution. Subsequently, Gef, and the monster more broadly, is better explored spatially as an itinerant crossing, following and extending Bennett:

\begin{abstract}
"I use the image of crossings rather than hybrids in order to avoid the suggestion that the segments of the crossing had a previous life in tact. There is a danger that the word hybridity conjures up the image of static entities coming together to form a compound" ${ }^{14}$
\end{abstract}

Gef reveals monstrous geographies as not just constituted through a relatively stabilised hyrbids of knowable matter, but as produced through the movement of a whole series or swarm of other constantly melding and mutable immaterialities, forces, modes of action and bodies. Monstrous geographies are incessant mobile crossings of trajectories that produce affects and effects as "emergent properties, emergent in that their ability to make something happen... [being] distinct from the sum of the vital force of each materiality [or force] considered alone" ${ }^{\prime 95}$ Taken in this way, the monster as an itinerant crossing, allows the apparently stable forms of which the monster is formed to be opened out at different speeds and with varying reaches. Gef emerges in multiple and incessantly itinerant folds of becoming - becoming-animal, becoming-human, becomingimaginary, becoming-(im)material. ${ }^{96}$ Consequently, in analysing monstrous geographies we must remain aware that the events and moments we chart in their emergence amount to thresholds - moments where the excessive and constant push of movement pauses or slows down, before opening to other emergent movements at different distances. As such, these events become akin to gradations rather than fixed points of being, with different intensities and durations, and holding out different capacities to affect and disclose, move and reach. Monsters and their geographies are forceful, itinerant, composed through different velocities and extent, and always emergent. 
Beyond this newfound awareness of itinerant crossings as fundamental to the constitution of monstrous geographies, what further significance does Gef provide? Performing a confounding of habitual categories, Gef's itinerant crossing renders him as Rai puts it, "radically new, for which no cultural code had prepared one for at all.."97 In affording alertness to the incessant movement of matter and the future, the monster reveals the capacity and potential for new formations exterior to seemingly stabilised relations between forms, categories and things. These occurrences of monstrosity chart events of mobile ontology, wherein difference crosses and morphs into other modes of alterity, and in so doing makes us vigilant to the ceaseless potential for further change. Furthermore, where difference-in-itself is made apparent, questions concerning the ontology of the monstrous can be answered anew. Indeed, the question of Gef 'actual' existence or origin becomes irrelevant or even anachronistic. ${ }^{98}$ Instead, as an incessant itinerant, Gef's "agency has no single locus, no mastermind, but is distributed across a swarm of various and variegated vibrant materialities" and other energetic forces of action, mobility and affect (and more besides). ${ }^{99}$ If, therefore, one were forced into answering the question 'was Gef actually real?' one would respond in the affirmative, with the proviso sounding something like 'he was real through his disclosures and affects, and the awareness he brings of the potential for shifting and ever-new conjunctions'. He was and continues to be a playful portent of irreducible becoming. Consequently one can argue, analyses of monsters, and the supernatural and the supernormal more generally, should not seek to seek out ultimate causes or foundational agencies, they should not seek to establish the 'truth' of this or that strange event, but should instead trace their mobile emergence in order enliven our senses to the movement of the new and new movements. ${ }^{100}$

How then can we summate Gef's significance? First, therefore, Gef underscores the importance of not having to seek out the 'reality' of monsters. Second, Gef's power lies in his ability to perform a demonstration. Akin to other monsters, he reveals an opening out and destabilisation of the given: for example, Gef makes matter mobile and suspect to unannounced potential, and underscores the power of monsters to reveal. Third, Gef is the monster as Derrida's arrivant: "the most weird and uncanny species of nature such as has never previously been heard or seen", as the reporter above states. Yet and moreover, Gef reveals the emphasis on movement 
and mobility that underpins the notion of the arrivant: Gef demonstrates that the arrivant, as a force of unforeseeable potential, is movement itself. Put simply, movement is potential and potential is movement. Through his hyper-mobility, strange reach and incessancy Gef speaks to the itinerant potentiality of crossing and movement, and at the same time, the movement of potentiality. Thus, we should care for Gef's significance because he speaks to how humans and non-humans are always in a mobile state of unrest and unknowable becoming and are caught amidst potential-movement and movement-potential. Gef the arrivant demonstrates that the (always) arriving unknown moves in our midst and, simultaneously, the unknown is a movement of potential. Gef is what Bennett calls the "creative not-quite-human force capable of producing the new": that which buzzes and subsists in and between everything is produced through and as movement. ${ }^{101}$ As other human geographers have shown, and as Gef enhances, the monster allows us think differently about difference and even the future itself.

Fourth, not only does Gef significance articulate the movement-potentiality of humanness and non-humanness as such, he also highlights how the analysis of monsters should seek to understand their movement and mobility to further underscore claims to their importance. Movement and mobility are both temporally and spatially constituted in that movement can be slow or quick, and more or less extensive in the distances covered. Focussing then upon the movement of monsters is a fruitful line of enquiry, particularly for human geographers. We might then wish to more fully explore the socio-cultural significance of the speed and distance of the mobile monster: for example, analysing the import of the speed at which the Zombie virus spreads, the extent of its travels and its destination. We may also want to explore the slow mobility of the zombie and where the zombie moves to and through, as constitutive of their significance and impact. One might also study how quickly the monster appears or moves into view - how fast some apparent socio-cultural abhorrence is deemed monstrous, for example. Or one might wish to research how mobile this categorisation is and how far it spreads - how a monstrous act, once classified as such, becomes universal or geographically differentiated, the speed at which this labelling occurs and its spatial reach. Movement and mobility in the geography of monsters has potential, like Gef himself. 


\section{Conclusion}

Through this morphing of parts and abilities - some strangely human, some familiarly nonhuman - Gef as monster cannot be seen as absolute other and cannot be simply distanced as the constitutive outside of the self. The monstrous, as explored here, refuses simple binaries of self and other, of same and (radically) different. Instead, the monster moves across and between the familiarly proximate, the unfamiliar distant, the unfamiliar proximate and the familiarly distant. In his incessant movement in-between and in-the-between of these multiple states, Gef becomes, to cite Dixon, "the absence of relationality"; he "is the refusal of the ordering principle itself." ${ }^{102}$ The talking mongoose as monster supplements or discloses through mobility simple classification and binary operations. In this paper, I have sought to explore how monstrous mobility has an affective and performative power which illuminates and extends what the monster can do. In particular I have emphasised that through incessant mobility the monster's potential to reveal potential as movement or movement as the unending push of becoming, generation and potential, becomes apparent. As such, we sense the potentiality of relation in Gef's movements and crossings, and he organises a sensibility that registers the movement of difference and the difference of movement. Moreover, and finally, this paper has argued that the 
ontology of the monstrous "operates not in the service of a pre-given end but for the sake of itself as process."

${ }^{103}$ Gef's ambiguous status as monster only reaffirms this further.

Registering the monster means letting go of a settled truth of or for the monster. Yet, and contra to the force of hope that the monster embodies in most human geographical interrogation, this movement always involve a risk. And herein lays the final reason for Gef's significance for the human geography of monsters. As such, this paper began by describing the monster's representative power as a warning, and as we shall see this characteristic still holds as we reach the end. These risks are the risks of whom or what is yet to come. And what or who is yet to come - what might move into view from these crossings - might not always be welcome. The monster can promise new ways of thinking and understanding, but we must still recognise that the monster represents a portent and remain aware of the monster's power as a warning. In particular, the partial ending to the Gef story reminds us that the power and risk of the monstrous continues to inhere in undermined coherency and a sense of vulnerability amongst witnesses.

So, in 1937 the Irvings sold the farm. In 1947 the new owner, former Army Lieutenant L. Graham, snared and clubbed a black and white animal ten yards from the farmhouse. Certain versions of the Gef story conclude with this, yet the animal failed to resemble Gef in size or colour. In July 1970, Walter McGraw, a reporter from Fate magazine, tracked down the reclusive Voirrey in England. She reflected that:

\begin{abstract}
"It was not a hoax and I wish it never happened...Yes, there was a little animal who talked and did all those other things. He said he was a mongoose and said we should call him Gef...but I do wish he had let us alone."
\end{abstract}

\footnotetext{
"Gef was very detrimental to my life. We were snubbed. The other children used to call me 'the spook'. I had to leave the Isle of Man and I hope that no one where I work now ever knows the story."104
} 
Voirrey refused to talk again about Gef and died $30^{\text {th }}$ April 2005 in Cheltenham. ${ }^{105}$

With the movement of ambiguity and potentiality of movement comes a warning of possible sadness for, or even fear of, what might become or what we might welcome in. This paper ends therefore with a warning so befitting of the term monster: they can affect a hope, but also a melancholic, apprehensive or fearful disposition to what, or whom, might become. In sum, monsters can move us to wonder and hope, but they can still bite.

\footnotetext{
${ }^{1}$ P. Dendle, 'Cryptozoology in the Medieval and Modern Worlds', Folklore 117 (2006), pp. 190-206, quotation p. 191.

${ }^{2}$ See, for example, the special editions edited by D.P. Dixon and S.M. Ruddick: 'Introduction: monstrous irruptions', Cultural Geographies 18 (2011), pp. 431-33; and 'Editorial: Monsters, monstrousness, and monstrous nature/s', Geoforum 48 (2013), pp. 237-238.

${ }^{3}$ I.G.R. Shaw, J.P. Jones III and M.K. Butterworth, 'The mosquito's umwelt, or one monster's ontology'. Geoforum 48, pp. 260-267; G. Davies, 'Writing biology with mutant mice: The monstrous potential of post genomic life', Geoforum 48 (2013), pp. 268-278; J. Lorimer and C. Driessen, 'Bovine biopolitics and the promise of monsters in the rewilding of Heck cattle', Geoforum 48 (2013), pp. 249-259; J. Kneale, 'Monstrous and haunted media: H. P. Lovecraft and early twentieth-century communications technology', Historical Geography 38 (2010), pp. 90-106.

${ }^{4}$ L-A. Gallacher, '(Fullmetal) alchemy: the monstrosity of reading words and pictures in shonen manga', Cultural Geographies 18 (2011), pp. 457-473, quotation p. 488.
} 
${ }^{5}$ D.P. Dixon, 'Wonder, horror and the hunt for La Bête in mid- $18^{\text {th }}$ century France, Geoforum 48 (2013), pp. 239248, quotation p. 242.

${ }^{6}$ Dixon and Ruddick 'Editorial', quotation p. 237; see also M. Foucault, 'Abnormal: Lectures at the Collège de France, 1974-1975' (New York, Picador, 2003)

${ }^{7} \mathrm{M}$. Shildrick, 'The body which is not one: dealing with differences', Body \& Society 5(1999), pp. 77-92, quotation p. 81.

8 J. J. Cohen, Monster Theory (Minneapolis, University of Minnesota Press, 1996), quotation p. 6.

${ }^{9}$ M. Shildrick, Embodying the Monster: Encounters with the Vulnerable Self (London, Sage, 2002), quotation p. 4.

${ }^{10}$ D. Haraway, 'The promises of monsters: a regenerative politics for inappropriate/d others' in L. Grossberg, C. Nelson, P. Treichler, eds., Cultural Studies (London, Routledge, 1992), pp. 63-124; D. Haraway, When Species Meet

(Minneapolis, University of Minnesota Press, 2008); J. Derrida, Points: Interviews, 1974-1994,P. Kamuf, et al., trans., E. Weber, ed. (Stanford, CA: Stanford University Press, 1995).

${ }^{11}$ Dixon and Ruddick, 'Introduction', quotation p. 432.

${ }^{12}$ Derrida, Points, quotation p. 386.

${ }^{13}$ See: E. Callow, The phynodeerree and other legends of the Isle of Man (London, J. Dean and Son, 1882); M. Killip, The folklore of the Isle of Man (London, Batsford, 1975); A. W. Moore, The folk lore of the Isle of Man: being an account of its myths, legends, superstitions, customs and proverbs (Douglas, Brown and Son, 1891); J. Randles, Supernatural Isle of Man (London, Robert Hale, 2003).

${ }^{14}$ Tradition has it that one must say "Laa Mie" ('good day' in Manx) when crossing the bridge and a practice continues where visitors pin notes and objects to nearby trees for good fortune, and in memory of the departed.

${ }^{15}$ The Isle of Man in this period was still, despite a decline in visitor levels in the 1930s, a popular tourist destination. Indeed, with the collapse of the mining industry in the early twentieth and the competition from foreign boats on the fishing industry, the island became increasingly dependent on visitors and tourism. See V. Robinson, D. McCarroll, eds., The Isle of Man: celebrating a sense of place (Liverpool, Liverpool University Press, 1990).

${ }^{16}$ See J. Randles, Supernatural, pages 67, 76, 154.

${ }^{17}$ See D. S. Katz, The Occult tradition: from the Renaissance to the present day (London, Cape, 2005); G. Lachman, A Dark Muse (London, Dedalus, 2003); A. Owen, The place of enchantment: British occultism and the culture of the modern (Chicago, University of Chicago Press, 2004).

$18 \mathrm{~J}$. Hazelgrove, Spiritualism and British society between the wars (Manchester, Manchester University Press, 2000), quotation p. 36; A. Calder, D. Sheridan, eds., Speak for yourself: A Mass-Observation anthology 19371949 (Oxford, Oxford University Press, 1985).

${ }^{19}$ H. Price, Confessions of a ghost hunter (New York, Causeway, 1974), quotation p. 85.

${ }^{20}$ Price, Confessions, p. 86.

${ }^{21}$ Ibid.

${ }^{22}$ N. Fodor, Between two worlds (New York, Parker Publishing, 1964), quotation p. 175.

${ }^{23}$ Price, Confessions, quotation p. 86.

${ }^{24}$ Letter from James Irving to Captain Dennis, 16 April 1934. The correspondences cited herein are archived in the Harry Price Library of Magical Literature at Senate House Library, University of London. The following files/classmarks were consulted: HPG/1/12/3; HPC/3F/1; $\mathrm{HPC} / 3 \mathrm{~F} / 2 ; \mathrm{HPC} / 3 \mathrm{~F} / 3 ; \mathrm{HPC} / 4 \mathrm{~A} / 27 ; \mathrm{HPC} / 4 \mathrm{~A} / 59$; $\mathrm{HPC} / 4 \mathrm{~B} / 61 ; \mathrm{HPC} / 4 \mathrm{~B} / 121 \mathrm{~A}$.

${ }^{25}$ H. Buller, 'Animal geographies II: Methods', Progress in Human Geography 38 (2014), pp. 1-11, quotation p. 2. 
${ }^{26}$ Ibid.

${ }^{27}$ Letter from James Irving to Captain Dennis, 10 November 1934.

${ }^{28}$ Letter from James Irving to Captain Dennis, 24 October 1934.

${ }^{29}$ Letter from James Irving to Captain Dennis, 2 November 1934.

${ }^{30}$ Letter from James Irving to Captain Dennis, 28 December 1934. Original underlined emphasis.

${ }^{31} \mathrm{H}$. Carrington and N. Fodor, Haunted people: the story of the poltergeist down the centuries (New York, E. P. Dutton and Co., 1951), quotation p. 183.

${ }^{32}$ Letter from James Irving to Captain Dennis, 16 April 1935.

${ }^{33}$ Furthermore, Gef also disclosed and moved between the common monstrous tropes of a fusion creature, as composed of hybrid parts (such as the Griffin), and fission creature wherein multiple incongrous elements are not temporally continuous (such as the Werewolf). See Gallacher, '(Fullmetal)'; N. Carroll, The Philosophy of Horror: Or, Paradoxes of the Heart (London, Routledge, 1990).

34 The letters concerning Gef are addressed to a Captain Dennis although the pseudonym Captain McDonald is used in certain accounts.

${ }^{35}$ Letter from James Irving to Captain Dennis, 2 November 1934. Original underlined emphasis.

${ }^{36}$ Letter from James Irving to Captain Dennis, 29 March 1935.

${ }^{37}$ Price, Confessions, quotation p. 85-86.

${ }^{38}$ Letter from James Irving to Captain Dennis, 10 November 1934. Original underlined emphasis.

${ }^{39}$ Two of his favourite songs were 'Isle of Capri' and 'Home on the Range', and he often announced his presence with a rendition of the (unofficial) Manx national anthem, Ellan Vannin.

${ }^{40} \mathrm{H}$. Price and R. S. Lambert, The haunting of Cashen's gap: a modern 'miracle' investigated (London, Metheun \& Co., 1936), quotation p. 34.

${ }^{41}$ Letter from James Irving to Captain Dennis, 2 November 1934.

${ }^{42}$ Letter from James Irving to Captain Dennis, 15 February 1935.

${ }^{43}$ Shildrick, Embodying, quotation p. 17.

${ }^{44}$ Shildrick 'The body', quotation p. 81

${ }^{45}$ Letter from James Irving to Captain Dennis, 19 June 1934. Original underlined emphasis.

${ }^{46}$ Letter from James Irving to Captain Dennis, 26 October 1934.

${ }^{47}$ Price, Confessions, quotation p. 93.

${ }^{48}$ Ibid., quotation p. 94.

${ }^{49}$ Letter from James Irving to Captain Dennis, 5 December 1932.

${ }^{50}$ Letter from James Irving to Captain Dennis, 16 April 1934. Original underlined emphasis.

${ }^{51}$ Letter from James Irving to Captain Dennis, 16 April 1934. Original underlined emphasis.

${ }^{52}$ Price and Lambert, Cashen's gap, quotation p. ix.

${ }^{53}$ The Manchester Guardian (5 November, 1936), quotation p. 7.

${ }^{54}$ The Times (5 November, 1936), quotation p. 4.

${ }^{55}$ See S. Pile, 'Distant feelings: telepathy and the problem of affect transfer over distance', Transactions of the Institute of British Geographers, 37(2012), pp. 44-59.

${ }^{56}$ The Stamp report, quotation paragraph 16, p. 9.

${ }^{57}$ The Times (5 November, 1936), quotation p. 4.

${ }^{58}$ Ibid.

${ }^{59}$ Ibid.

${ }^{60}$ Ibid.; The Times (6 November 1936), quotation p. 4; Manchester Guardian (6 November 1936), quotation p. 3.

${ }^{61}$ The Times (5 November, 1936), quotation p. 4.

${ }^{62}$ The Manchester Guardian (5 November, 1936), quotation p. 7. 
${ }^{63} \mathrm{Ibid}$; there was a short debate between Swift and Beresford over the plural of mongoose with the Judge settling on 'mongi.'

${ }^{64}$ Fodor, Between two worlds, quotation p. 183.

${ }^{65}$ The Times (6 November 1936), quotation p. 4.

${ }^{66}$ D. Wilby (2006), 'Lambert v Levita 1936', http://www.bbc.co.uk/historyofthebbc/resources/bbcandgov/pdf/mongoose.pdf, ONLINE. Last accessed 30 July 2014.

${ }^{67}$ A. Briggs, The golden age of wireless: the history of broadcasting in the United Kingdom (volume II) (London, Oxford University Press, 1965).

${ }^{68}$ The Times (7 November 1936), quotation p. 4.

${ }^{69}$ The Stamp report, paragraph 19, quotation p. 10.

${ }^{70}$ Ibid., paragraph 49, quotation p. 28.

${ }^{71}$ Fodor, Between two worlds, quotation p. 173.

${ }^{72}$ Carrington and Fodor, Haunted people, quotation p. 208.

${ }^{73}$ Carrington and Fodor, Haunted people, quotation p. 192. Emphasis added.

${ }^{74}$ Price and Lambert, Cashen's gap, quotation pp. 15-16.

${ }^{75}$ Ibid., quotation p. 5.

${ }^{76}$ Carrington and Fodor, Haunted people, quotation p. 178.

${ }^{77}$ Ibid., quotation p. 210.

78 Ibid.

${ }^{79}$ Price and Lambert, Cashen's gap, quotation pp. 154-155.

${ }^{80}$ Letter from James Irving to Captain Dennis, 16 April 1934. Original underlined emphasis.

${ }^{81}$ Carrington and Fodor, Haunted people, quotation p. 201.

${ }^{82}$ Letter from James Irving to Captain Dennis, 11 November 1934. Original underlined emphasis.

${ }^{83}$ Letter from James Irving to Captain Dennis, 19 June 1934. Original underlined emphasis.

${ }^{84}$ Kneale, 'Haunted and Monstrous Media'.

85 J. Bennett, The enchantment of modern life: Attachments, crossings and ethics (Princeton, NJ, Princeton University Press, 2001), quotation p. 19.

${ }^{86}$ Letter from James Irving to Captain Dennis 23 December 1932. Original underlined emphasis.

${ }^{87}$ Letter from James Irving to Captain Dennis, 30 November 1934.

${ }^{88}$ Letter from James Irving to Captain Dennis, 16 April 1934. Original underlined emphasis.

${ }^{89}$ Letter from F. Martin Duncan to Harry Price, 23 April 1935.

90 Price and Lambert, Cashen's gap, quotation p. 182.

${ }^{91}$ The Isle of Man Examiner (19 February, 1932), quotation p. 7.

${ }^{92}$ Carrington and Fodor, Haunted people, quotation p. 174.

93 Price and Lambert, Cashen's gap, quotation p. 154; D. Williams, Deformed discourse: function of the monster in medieval thought and literature (Exeter, University of Exeter Press, 1999); L. Datson and K. Park, Wonders and the order of nature, 1150-1750 (New York, Zone Books, 2001).

${ }^{94}$ Bennett, Enchantment, quotation p. 31.

95 J. Bennett, Vibrant Matter: A Political Ecology of Things (Durham, NC, Duke University Press, 2010)

${ }^{96}$ G. Deleuze and F. Guattari, A Thousand Plateaus: Capitalism and Schizophrenia (Minneapolis, MN, University of Minnesota Press, 1987)

${ }^{97}$ A. S. Rai, 'Of monsters: biopower, terrorism and excess in genealogies of monstrosity', Cultural Studies 18 (2004), pp. 538-570, quotation p. 553. 
${ }^{98}$ We have seen many apparent explanations for Gef in the paper, such as the monster as product of James Irving's immobilised imagination. However, one of the common explanations is that Voirrey was the 'cause' of Gef through ventriloquism (many commentators point to how Gef disappeared when Voirrey was not there). Other explanations point to Voirrey's loneliness (her brother, who helped build the farm, and her other sister both lived in the UK at the time) or even her 'hormonal state' as a (pre-)pubescent girl. This latter is a common explanation of supernatural phenomenon (see for example The Enflield Poltergeist case) and echoes ideas of monstrous femininity. See B. Creed, The Monstrous-Feminine: Film, Feminism, Psychoanalysis (New York, Routledge, 2007); M. England, 'Breached Bodies and Home Invasions: Horrific representations of the feminized body and home', Gender, Place and Culture: A Journal Of Feminist Geography 13 (4) (2006), p. 353-363.

${ }^{99} \mathrm{Ibid}$, quotation p. 96

${ }^{100}$ See also: J. Holloway and J. Kneale, 'Locating haunting: a ghost-hunter's guide', Cultural Geographies 15 (2008), p. 297-312.

${ }^{101}$ Bennett, Vibrant, quotation p. 118. Original emphasis.

${ }^{102}$ D. Dixon, 'The blade and the claw: science, art and the creation of the lab-borne monster', Social and Cultural Geography 9 (2008), p. 681; Ibid. p. 686.

${ }^{103}$ Bennett, Vibrant, quotation p. 118.

${ }^{104}$ W. McGraw, 'Gef the talking mongoose - 30 years later', Fate: True Stories of the Unknown (July 1970), quotations p. $82 \&$ p. 81-82.

${ }^{105}$ Gef continues to move imaginations and is still not at rest. A Facebook group 'Gef the talking mongoose' has 702 members (https://www.facebook.com/groups/11118503209/, Last accessed $16^{\text {th }}$ March 2016) and is very active; a YouTube video of a 'pilgrimage' to Doarlish Cashen has had 16,500 views (http://youtu.be/OFBvGS3ymdc, Last accessed $16^{\text {th }}$ March 2016); and Gef is the subject of a forthcoming biography (to be published by Strange Attractor Press) by Christopher Josiffe who works as a cataloguer at Senate House Library, University of London.

\section{Acknowledgements}

I would like to sincerely thank Tim Cresswell for his advice and persistence with the paper, and the anonymous referees whose insight and comments were both insightful and very helpful. I would also like to thank Miss S for putting up with me and my obsession with a talking mongoose from the Isle of Man, and for being an excellent informal research assistant on a 'pilgrimage' to Doarlish Cashen in 2010.

\section{Author biography}

Julian Holloway is a Lecturer in Human Geography at Manchester Metropolitan University. He writes on religion and spirituality, and is interested in geographies of the Occult and Forteana. 
Figure 1: The farmhouse at Doarlish Cashen, with Voirrey and James Irving (Image courtesy of The Mary Evan Picture Library). $385 \times 285 \mathrm{~mm}(300 \times 300 \mathrm{DPI})$ 
Figure 2: 'Drawing by George Scott of Gef from particulars supplied by Mr. Irving and the 'Mongoose Himself'. Frontispiece of Price and Lambert's The Haunting of Cashen's Gap: A Modern 'Miracle' Investigated (Image courtesy of The Mary Evan Picture Library). $523 \times 327 \mathrm{~mm}(300 \times 300 \mathrm{DPI})$ 